\title{
ENVIRONMENTALLY FRIENDLY REPRODUCTION AND PRODUCT IN CULTIVATION OF A NEW SOCIAL ORDER
}

\author{
ЭКОЛОГИЧЕСКИ ЧИСТЫЕ ВОСПРОИЗВОДСТВО \\ И ПРОДУКТ В КУЛЬТИВИРОВАНИИ \\ НОВОГО ОБЩЕСТВЕННОГО УКЛАДА
}

\section{Vladimir Shedyakov ${ }^{1}$}

DOI: https://doi.org/10.30525/978-9934-26-049-0-13

Abstract. The aim of the work is to analyse the range of possibilities for environmentally friendly reproduction not so much as a separate direction (in particular, the green economy), but as a pivotal direction of structural transformations on a paradigmatic scale. The emphasis on the characteristics of nature similarity, friendliness, mutual interest, tolerance, equality, and equivalence is recorded as an important element of global and national changes. Close entry into local communities and respect for their value-sense complexes becomes an element of the convergence strategy. The formation of a social order that cultivates environmentally friendly reproduction is closely related to the unity of public and private interests, mechanisms of partnership and acts as the foundation of social state with power (in particular, government) responsible to the people. The methodology of both research and presentation of material integrates an abstract-theoretical approach with a concrete-historical one. The cultivation of the green economy is associated not only with the necessary increase in the competitiveness of products, but also with an inalienable change in the entire way of life, the formation of a new social order (including in the economy). The complex development of the environment for interaction of business entities is also considered as a significant factor in national, regional and international security, and the focus on environmentally friendly reproduction and products as a promising direction of integration. Protection of domestic producers of goods and services, creators of tangible and intangible products is an important area of ensuring real economic sovereignty and promoting

\footnotetext{
${ }^{1}$ Doctor of Sociological Sciences, Candidate of Economic Sciences,
} Free-lance, Ukraine 
national interests. The growth of measures of pro-social development and the realization of the giftedness of the population in creative (primarily, scientific and intellectual) activities is becoming an indispensable necessity for organic socio-economic development. The organic nature of changes requires being based on both global and own patterns and peculiarities, their basic value-sense complexes and traditions, social foundations and political forms. Accordingly, the search for alternative dominant models of a combination of reasonable individual initiative and state regulation, based on broad theoretical and methodological research and explicit applied sound, is especially in demand when the paradigmatic level changes. On the contrary, training (often outdated and non-working) fragments of Western social science does not galvanize the socio-political corpse of a fading social paradigm. Such attempts especially clearly demonstrate their inconsistency when the practical-theoretical paradigm is changed, when attempts to apply clichés from the rump of the conceptual apparatus of Western modernity are not able to confirm their practical truth, to justify the use of terminology. Successful overcoming of the next evolutionary barrier and overcoming the contours of tension requires the development of adequate theoretical and practical tools. The postponement of urgent changes due to the global epidemic was not only additionally updated, but also increased the degree of their public relevance. Latently, there is the cultivation of new tools, the development of the opening opportunities for the formation of a higher moral order of environmentally friendly means of self-realization and cooperation: by no means only technical and technological, but also socioeconomic and financial too.

«Недра не подведут, если не подведут люди» (И. М. Губкин)

\section{1. Вступление}

Природа создала человека как возможность разумного пути развития. Так, разумной и является экономика, включившая в себя нравственные представления, в частности, о справедливом, должном, желательном, - относительно изменений природы, общества, человека. Между тем, с ростом могущества человечества возрастает и потенциал, которым оно может оперировать. И новая эпоха резко повышает вероятность новых волн массовых угроз, в т.ч. - для хозяйствования. 
Их обуздание соответственно позитивному освоению открывающихся горизонтов развития требует одновременного решения задач природоподобия и очеловечивания, дружелюбия и решительного отстаивания интересов и идентичности. Дело не только в том, что таким образом расширяется ниша присутствия на рынках со своей, подчас уникальной продукцией, но и в том, что это направление сопряжено с коренным изменением всего образа жизни человечества [1-5].

Период сфокусированных общественных преобразований, с одной стороны, расширяет рамки возможностей, с другой, - формирует основание последующих социально-экономических трансформаций и, соответственно, характер использования этого времени во многом предопределяет дальнейший «коридор свободы» как во внутренней, так и в международной жизни. При этом подъём одной страны при ослабевании другой по закону неравномерности исторического развития обостряет конфликтность эпохи. Очередной парадигмальный скачок в развитии ойкумены объективно требует соответствующих изменений стратегий социально-экономического развития и защиты национальных интересов. Их коренная модернизация тем насущней, что осуществляется переход к принципиальной многополюсности и признанию права на разнообразие. И во многом именно лидеры, способные понимать и работать в интересах собственного культурно-цивилизационного мира, становятся весомым фактором выявления и эффективного использования глобальных процессов. Соответственно, смена мирового тренда - это и необходимость смены элит: не умеющие открыть диапазон возможностей новой эпохи для субъектов хозяйствования и народа как целого должны уйти. При этом важнейшими субъектами поиска и культивирования новых моделей общежития (как и защиты населения) проявили себя отнюдь не транснациональные корпорации или международные организации, а именно государства. Причём детерминанты общественной организационно-управленческой и технико-технологической патогенности вариативны и комбинируемы, что открывает дополнительные перспективы направленной селекции определённых признаков. Изощрённость технологий дестабилизации влияет на манипулирование массовым сознанием. Стойкость и критичность в восприятии информации в её половодье становятся важным элементом иммунитета культурно-цивилизацион- 
ного мира. А психологическая устойчивость в сохранении и развитии его базовых ценностно-смысловых комплексов коррелирует с общественной идеологией, в частности, - отношением к жизни и смерти, самоуважением, сотворчеством и т.п. Вместе с тем, растёт искус, уводя от внутренних проблем внимание населения, усиливать агрессию внешней политики и манипулятивность подачи информации. Процессы мировых трансформаций ещё раз демонстрируют: у каждого из субъектов истории своя комбинация преимуществ и недостатков. Их осознание и учёт - важнейший элемент создания эффективного Сверхпроекта развития культурно-цивилизационного мира и уяснения путей гармонии стратегии, тактики и оператики осуществления трансформации жизненного уклада.

Ориентация на приоритет экологии (включая и экологию человека) - практическая реализация идей антропокосмизма, моральной экономики и этики хозяйствования, тесно вплетённых в подходы с позиций социального сотрудничества и кооперации в природной и общественной жизни. Соответственно, научно-методологическая база текста - исследования и раздумья Аристотеля, Ж. И. Алфёрова, Н. А. Бердяева, В. И. Вернадского, Б. Жувенеля, П. А. Кропоткина, И. И. Мечникова, Р. Оуэна, И. Н. Острецова, В. Н. Сагатовского, В. С. Соловьёва, К. А. Тимирязева, Э. Тоффлера, Н. А. Умова, Н. Ф. Фёдорова, А. В. Чаянова, К. Э. Циолковского, А. Л. Чижевского, А. Швейцера, а также М. Букчина, Дж. Джекобс, Р. Л. Карсон, Р. Костанцы, С. А. Липиной, Л. Маргулис, В. А. Медведева, Э. Ф. Шумахера. Анализ путей взаимообогащения городского и сельского укладов жизни проводили П. П. Великий, Е. М. Воробьёв, Г. Р. Габидуллина, Р. К. Иванова, В. Л. Козлов, О. В. Лылова, М. М. Макеенко, А. П. Мамалуй, В. А. Правоторов, Н. А. Рожков, Р. В. Рывкина, И. Е. Ткаченко, И. Г. Ушачёв, Г. С. Широкалова, Е. А. Якуба.

Задача текста - подытоживание изучения «зелёной» экономики в контексте парадигмальных изменений для оптимизации их проведения.

\section{2. Парадигмальные трансформации уклада общественной жизни}

Подходы социализированного, народного устройства общества и государства становятся последовательно реализуемыми при охвате производственных отношений, проявляясь, в частности, не только в 
ориентации на создание экологически чистого продукта, но и в тяготении к экологически чистым циклам воспроизводства. Акцентирование «зелёной» экономики - отзвук трансформаций глобального масштаба, создающих предпосылки для новых ниш хозяйственного преуспеяния и общественной устойчивости. Воплощение самобытных моделей социального (народного, социализированного) государства требует расширения и соответствующего сектора хозяйствования, и сквозного значения подобных принципов. Влияние требований экологии (в т.ч. экологии человека) настолько усиливается, что природосбережение входит в адекватное новой эпохе понимание общественной формы производительного труда. Всемирный исторический процесс обнаружил очередной период форсированных преобразований парадигмального уровня, кардинально меняющих условия конвергенции хозяйствования. Культурно-цивилизационные миры проживают свои стадии отнюдь не синхронно, так что их конкуренция во многом зависит от качества использования специфики хронологически наложившихся друг на друга условий и характеристик. Разумеется, варианты всякой парадигмы общественного развития несут собственные комбинации возможностей и угроз, меняя востребованность ресурсов и влияя на благоприятные и осложнённые направления трансформаций. Осуществление глобального поворота от международного разделения деятельности и от глобальной же шаблонизации к возрождению идентичности культурно-цивилизационных миров зафиксировало переход к постглобальному состоянию общественной среды хозяйствования [6-11]. Так, становление устойчивого состояния гармоничной социобиологической целостности требует достижения динамичного единства мер обеспечения безопасности и развития. Значительная доля социальных болезней порождается застоем творческой энергии общества, окостенением его политической и хозяйственной системы. Соответственно, экономика включается в качестве подсистемы в природную среду. Ресурсно-ориентированная экономика не может не признавать первоочередного значения экологических факторов безопасности и развития общества, в частности - при изучении обоснованности применения технологий. Реактуализируется классическое разделение собственно разумной «экономики» и «хрематистики» неудержимой гонки за наживой [12-14]. С одной стороны, это предполагает возврат на новом витке общественного развития к анти- 
потребительству и модели поведения, обеспечивающей удовлетворение лишь базовых сущностных сил с переложением их существенной части на общество и государство. Соответственно, новая эпоха благоприятна для ограничения в потребительстве и стяжательстве / накопительстве и требует максимизации социального поля участников творческого процесса. В частности, надлежит принять решительные меры по преодолению пропасти между богатыми и бедными в возможности доступности к общественным благам, вообще - в их укладе жизни. Между тем, например, для протестантизма сначала непрерывный и беспощадный промышленный рост, а затем - спекулятивно-финансовые гирлянды на фондово-страховых рынках довольно долго были вознесены в статус доказательства исключительности, важнейшей добродетели, а преуспеяние стало мерилом богоизбранности. При этом традиции культивирования экологической стабильности и бережного отношения к природе это очевидное свойство незападных стилей жизни, на Западе же долгое время считались атрибутом альтернативных и андеграундных учений. С другой, - базирование на ключевых ценностно-смысловых комплексах своих культурно-цивилизационных миров предполагает внедрение в международную практику отношений, не предполагающих насильственное вмешательство во внутренние дела иных миров. Моральная экономика основана на фундаменте народных представлений о справедливом, нормативном, обязательном. Различающиеся сочетания приоритетов, идеалов, ценностей, возможностей не могут не выливаться в собственные формы реализации требований эпохи. А естественное расхождение исторического опыта, социального традиций, возможностей отражается на дереве целей и этапах преобразований [15-18].

Между тем, прежняя устойчивая динамическая система с конкуренцией и партнёрством противостоящих политико-экономических лагерей отошла в прошлое. Некоторое время международная жизнь занималась эквилибристикой, пытаясь воплотить модель единоличного господства Запада при жёстком отделении экономики услуг в странах-лидерах от аграрно-индустриальных зон с устаревшими технологиями в истощаемом окружении. Но высокомерие силы (arrogance of power) рождает безнадёжную хрупкость миропорядка. Это неустойчивое состояние международных отношений использовалось его фаворитами для корыстного присвоения преимуществ от своего положе- 
ния. Для решения узкокорыстных вопросов походя использовались и природа, и все прочие народы, а их интересы просто игнорировались. Со временем попытки гегемонии как навязывания удобных для себя порядков: ресурсами военными, дипломатическими, культурными, мировоззренческими - перестали давать результат. Культурно-цивилизационный мир Запада, патологизировавшись, принял и человеконенавистнические формы, передав свой творческий запал совсем иным субъектам международной жизни. Закономерно: дестабилизация Запада протестным движением - весомый фактор постглобальных трансформаций. Сохраняя мощь, Запад утратил динамизм и привлекательность. Вообще богатство бывших метрополий по «чистоте» своего происхождения крайне уязвимо: его легитимность (что дополнительно показали протестные движения «жёлтых жилетов», «Occupy Wall Street» и др., раскол между «Black Lives Matter» с «ANTIFA» и «Proud boys») серьёзно подрывается веками ограбления колоний и зависимых государств. Не меньшее возмущение вызывают попытки воспроизводства аналогий некоторых черт в «современной работорговле» биоматериалами и экономическими ресурсами, а также наслоения духовного отчуждения (не говоря уж об отчуждении самой человеческой жизни). Видимость изобилия для платежеспособных (при нарастании абсолютного и относительного обнищания масс населения, безработице и обессмысливании жизни) скрывает действительность, а обилие форм манипулирования и пропаганды - глубинную сущность происходящего там. Как выявляет анализ исторического опыта и его сравнение с формированием черт постсовременности, обещанная либерализмом эмансипация личности оборачивается высвобождением животных инстинктов с утратой созидательного порыва модерна.

Природа же постглобализма оказывается восприимчивой к социальным комбинациям потребительского самоограничения в пользу творческого процесса и индивидуальной самодисциплины ради общественного развития и реализации сущностных сил. Вместе с тем, суть творчества отнюдь не редуцируется к родовым (по сути своей - животным) стандартам типа «посадить дерево, построить дом, вырастить ребёнка»: забота о жилище, потомстве, еде и т.д. свойственна и зверям. Дело - в просоциальных развитии и реализации уникальной одарённости каждого, что интегрирует жизнь человека и народа. Задача, 
разумеется, заключается не в регрессе, а в восхождении, в частности, через наполнение базового, природно-биологического уровня высокими общественными и духовными смыслами, не в опрощении, а в восхождении форм жизни. При этом нравственно-духовный императив целеполагания прямо противостоит деградации и хаосу: как при структурировании сакрального, так и в повседневной действительности. Соответственно, обеспечение адекватных эпохе форм развития базовых ценностно-смысловых комплексов культурно-цивилизационных миров - условие продуктивного развития сущностных сил человека, гармоничного развёртывания и реализации в творчестве комплекса его дарований. Суверенность и идентичность как защита своих взглядов на жизнь, своего миропонимания, своих смыслов и ценностей, своих социокультурных стилистик - необходимость органичного развития. Культивирование устойчивой и плодотворной традиции - не только надёжная основа сохранения национальной идентичности, но и достойная почва для успешных инноваций: как технико-технологических, так и социально-экономических. При этом важно, в чём видеть источник власти: в своём ли народе, в замыслах элиты, в прихотях агрессивных меньшинств или же в интересах внешних центров. Так, схемы внешнего управления включают механизмы господства / подчинения экономические, военные, идеологические, информационные, правовые, всё чаще склоняя к вовлечению в чуждое культурно-цивилизационное образование. При этом с абсолютным и относительным (в сравнении с конкурирующими центрами силы) ослабеванием гегемона и обнажением его внутренних противоречий компенсаторно нарастает его агрессивность.

Между тем, периодические трансформации парадигмального качества - неизбежность развития как, в частности, «повивальная бабка истории». Но сам период форсированных изменений, разумеется, - это не время приращения на установившейся основе, соответственно, вовсе не эпоха процветания, а эра кризиса и выхода на поверхность накопленных противоречий, поляризации общества и обострения борьбы. Сущность взаимоподдержки традиций и инноваций общественного развития - в политико-экономическом устройстве порядка жизни, который, чтобы быть созидательным, должен восприниматься народом как справедливый, должный. Для этого, в свою очередь, не должно существовать при- 
вилегий для власть имущих и агрессивных меньшинств, размежевание не должно прикрываться лживыми лозунгами и т.д. Переход к постглобальности - время оформления постглобализма. Разумеется, фавориты прежнего мироустройства пытаются цепляться за исчезающие привилегии, консервируя расползающуюся ткань господства за счёт деиндустриализации, финансово-спекулятивного господства, подрыва возможностей соперников и информационного манипулирования. Так, порой развитие альтернативы - не в движении от хорошего к превосходному, а в том, что предпочесть - развитие (пусть и с присущими для всего живого эксцессами) или сон в анабиозе. Осуществление парадигмальных трансформаций требует адекватности в их восприятии, принятии и осуществлении организационно-управленческих решений по единству конвергенции и самобытности.

В людях же заложено доброе начало, берущее верх всякий раз, когда под угрозой и Ойкумена, и окружающая среда. Проявлением его является осознанная потребность в повышении экологической культуры. Одновременно логика истории ведёт от попыток культуртрегерского неоколониализма с насаждением метрополиями удобных для себя моделей к полилогу культур и гибкой геометрии подходов. Зависимость от импорта - не только угроза национальной безопасности, но и симптом тяжкого заболевания общественной системы. На смену условной «эре Америки» не приходит эпоха кого-либо другого. Скорее, речь идёт вообще о кардинальном изменении ресурсно-методологических баз развития. Переход к логике свободы является, вместе с тем, отказом от единственности любого базиса общежития. Развитие ойкумены отходит от схем «центр(ы) - полупериферия - периферия» к гибкому и изменчивому взаимодействию разноуровневых акторов, где ведущие роли играют культурно-цивилизационные миры, имеющие в качестве своих духовно-нравственных стержней базовые ценностно-смысловые комплексы. Они становятся мультипликаторами силы народов и создают миссию и мораль государства, наращивая социокультурный потенциал общества. Опора на них позволяет не только разбудить и сконцентрировать, но и сэкономить социальную энергию. Они же в конечном итоге предопределяют, какое именно состояние общественного пространства рассматривается как пригодное для жизни и развития, т.е. формируют консенсус. Именно они, закрепляясь матрицами ментальных кодов 
народов, влияют на состояние и вектор трансформаций эмоционального интеллекта общества, предопределяют общественные предпочтения, поведение и исторический выбор. Соответственно, на их основе появляется возможность уточнить модель развития и создать более органичное представление о желаемом и достойном. При этом смысловые иерархии, заложенные в предметах духовной и материальной культуры, фиксируются и в языковой системе. Очевидно, общекультурные признаки становятся важнее генетических особенностей. Состояние и динамика народной нравственности фиксируется подвижками в совести, справедливости, доверии как условиях состоятельности общественной целостности. Именно так вокруг осей ценностно-смысловых комплексов обеспечивают безопасность и развитие культурно-цивилизационные мира. Впрочем, по общему правилу, новый вид создается на границе популяции - там, где нужно бороться за выживание, конкурировать и меняться.

При том назревшие радикальные изменения общественного пространства являются всеобъемлющими; они касаются существа политико-экономических и социокультурных отношений, образа жизни, геостратегического позиционирования и т.д. Ойкумена движется от консьюмеризма и/или накопительства, когда ВВП определяется всего лишь массивом уничтоженного сырья, а гонка сверхпотребительства как извращённого стимула лихорадочного производства дополняется громадным массивом массового недопотребления предметов первой необходимости, к творческой (прежде всего, интеллектуально-духовной) активности как форме развёртывания комплекса дарований личности, естественно акцентируя «зелёные» воспроизводственные циклы. Протей моды подстёгивал и диктовал образ жизни, но сам плотно завяз в экспансии рынков. Приоритет денег автоматически девальвировал жизнь, обрекал на понижение уровня социальной ответственности и оскудение общества. Эпидемия приобретательства лишь подменяла выявление подлинных жизненных целей и ценностей, искажала смыслы, была мощным фактором иррационализации реальности и её восприятия. Спасение человека от стереотипов и идолов общества массового потребления - необходимое условие нравственного созидания. При этом закладываются основы преодоления неадекватных задачам эпохи как, с одной стороны, непотизма и кумовства, так и, с другой, уродливых сочетаний эпигонами либерализма 
и национализма. Вымывание пропагандой потребительского образа жизни, навязывание погони за видимыми чертами «успеха» разъедает полотно социальности. Между тем, страны, стабильно демонстрировавшие высокие достижения во всех областях социального общежития, как правило, основывались на широком объединении усилий различных слоёв населения на основах гражданского согласия и достижения соборности общественного устройства ради творчества во всех сферах жизни. Для органичности развития общества необходимо воспитывать не потребителя, а созидателя, укоренёёного в пластах культуры и овладевшего социальным наследием духовно богатого человека. Отчуждение становилось всепроникающим, духовные запросы человека игнорировались, а его жизненные силы подавлялись; предлагалось существовать ради чуждых задач - или умереть ради них же. Антигуманизм, расчеловечивание органично порождают фашизм (в частности, ресурсами дехристианизации), посягающий не только на право самоопределения, право развития (восхождения в историческом процессе), но и на само право на жизнь, сталкивающий в резервации антиутопий, талантливо отображённых Носовым, Оруэллом и Брэдбэри. Языковая и, в целом, культурная сегрегация стала весомым направлением этноцида в стратегии империализма малых народов.

Ныне возможности рыночной концентрации исчерпаны, этот тип международного разделения деятельности и организации миропорядка достиг предела насыщения и подточил собственные социальные, политические, экономические основания. Средний класс повторяет судьбу пролетариата. Причём текучая природа регулируемых процессов одновременно инициируется как особенностями новонарождающейся общественной среды, так и свойствами форсированного переходного периода. Ойкумена ныне - в процессе реализации открывшегося «коридора свободы». Если ранее человек реализовывался в строгих рамках предопределённой рождением жизненной дороги, то сегодня в социальном масштабе свобода выбора в продуцировании смыслов сменила прежнюю свободу от выбора с низведением к животно-вещной репродукции. Одновременно самоизоляция: людей, регионов, государств - ускорила изменения в социальном коммуницировании, став толком и лакмусовой бумагой трансформаций. Рассредоточение и автаркия переформатируют состояние обществен- 
ной среды, повышая роль и готовности работы со смыслами, и стратегического планирования. Причём есть все основания утверждать, что мир дистанционного обучения, удалённых мест работы и вынесенных за пределы мегаполисов мест проживания вовсе не уходит с волной эпидемии; но и многие из узлов промышленного производства требуют своей территориальной концентрации. Всё это требует отражения в новом прочтении возможностей «зелёной» экономики, сращивания характеристик когда-то кардинально отличных «городского» и «сельского» образа жизни.

\section{3. Установление нового баланса стратегии, тактики}

\section{и оператики - условие эффективного ответа на вызовы времени}

Совместные усилия в нарабатывании экологических стандартов жизнедеятельности - сложный и противоречивый процесс. Наиболее могущественные страны могут пытаться, с одной стороны, не связывать себя обязательствами или же трактовать их в свою пользу, с другой, - использовать требования как средство торможения конкурентов. Кардинальные всемирные трансформации востребуют адекватной оптимизации национальных стратегий. Культурно-цивилизационные миры для сохранения своей идентичности и популяции нуждаются в собственных независимых системах жизнеобеспечения. Соответственно, если постглобальность характеризует объективное состояние ойкумены (в частности, международной жизни), то постглобализм - субъективное отражение его, качество осознания и использования, прежде всего, в осуществлении баланса стратегии, тактики и оператики. Наиболее выпукло постглобализм проявляется как качество, во-первых, понимания / восприятия / представлений и, во-вторых, освоения складывающейся действительности в рамках материальных и духовных практик. «Информационный взрыв» повысил значение деятельности по оценке, отбору и переработке знаний, что естественным образом повышает общественную ценность одарённости и компетентности, фиксируясь в явлениях меритократии и экспертократии. Сокращение срока для принятия и осуществления решений, на протяжение которого действия являются продуктивными, увеличивает как роль допущенных к функциям власти и управления, так и статус народного контроля за их деятельностью (в частности, 
для препятствия узкокорыстному эгоизму, бюрократической коросте и административной коррупции). Стратегическое целеполагание существенная характеристика не только состояния, но и устремлений (следовательно, динамики) государства. Существо происходящего перехода связано с преодолением материальной доминанты жизнедеятельности и общественной необходимостью максимизации поля просоциальных развёртывания и использования сугубо индивидуального комплекса одарённостей при перерастании стадиального (формационного, этапного) развития. Расхожее доктринёрство либералов и рыночный фундаментализм очевидным образом не способны предоставить надёжные теоретико-методологические ответы на запросы истории.

Массовое недовольство прежним образом жизни - отнюдь не случайный эпизод, созданный несходством мировоззрений или предвыборной борьбой. Стремительный рост протестного движения на Западе - показатель новой реальности: как формирования иной, отличной от привычной, общественной парадигмы, так и периода форсированных трансформаций, а отнюдь не только гротеска карнавалов внутренней партийно-политической суеты. В протестном движении легко читаются потоки, связанные не только с манипулированием толпой погромщиков и попытками сделать общество более управляемым, сломав традиционные институты, но и с выходом наружу фундаментальных общественных противоречий. Причём крайности, как обычно, смыкаются: с одной стороны, ультралиберализм и национал-фундаментализм обретают партнёра друг в друге (порой патологизируясь до «эксплуатации наоборот»), с другой, - инновации и традиции взаимно резонируют, противостоя дискриминиции. Усиливаются попытки манипулирования тем же протестным движением и жупела «внешней угрозы» для навязывания ойкумене будущего в стиле антиутопий с всевластием монополий, основанным на долларе и флоте, и подкупленным комфортом деидеологизированным человечеством.

Тем самым, для человечества актуализировался вопрос оптимизации использования периода «зацикленности Запада на себя», в частности, для освобождения от внешней зависимости и упрочения суверенности. Очевидно, что требуется в наибольшей степени использовать открывшийся шанс эффективной как защиты своих национальных интересов, так и тесно связанного с этим выращивания более спра- 
ведливого и прогрессивного порядка мировой жизни. Если послевоенный мир сумел осуществить материально-политическую деколонизацию, теперь же на повестке дня - духовно-нравственная. При этом, естественно, у каждого субъекта международного процесса свой набор преимуществ и уязвимостей, цели и проекты, базовые ценностно-смысловые комплексы и политико-экономические уклады. Соответственно, если международному капиталу не важно, где обеспечивать для себя рост нормы прибыли и как осуществлять минимизацию затрат, то для национальных государств, напротив, основная задача - именно оптимизация (в частности, средствами развития «зелёной» экономики) сочетания культивирования условий жизни и творчества своего народа с отстаиванием своего суверенитета; так что меры обеспечения реального народовластия и независимости тесно переплетаются и подкрепляют друг друга, находя подкрепление в экологически чистых воспроизводственных циклах и передовых технико-технологических укладах. При этом растут требования к элите: она должна быть от основных социальных групп созидателей, ощущать ответственность перед народом, выступать носителем исторического гуманизма и быть способной к историческому творчеству. Однако, необходимо остерегаться обыкновения США решать свои внутренние проблемы за счёт внешних агрессий, усиления попыток вмешательств во внутренние дела суверенных государств и обирания прочих культурно-цивилизационных миров.

На переломе особенно выпукло выступает преобладание социально-политического смысла эффективности и конкурентоспособности общественной системы над её способностью к утилитарно-коммерческому профиту. Социально-политическая доминанта экономического роста (в частности, промышленной политики государства) обеспечивается особенностями формируемых Сверхпроектов. Активная роль государства в поддержании общественной гармонии проявляется не только в обеспечении безопасности своего культурно-цивилизационного мира, но и, в частности, в таких эффективных средствах его обеспечения и развития, как формирование и направление такого Сверхпроекта. Соответственно, государственная миссия, воплощённая в череде Сверхпроектов, оберегает жизненно важные условия существования и развития культурно-цивилизационных миров. В частно- 
сти, и вознаграждение за него должно быть достаточно для гарантирования высоких стандартов жизни, и нетрудовые доходы не могут быть основанием материального неравенства и социального престижа. Сегодня наиболее острое противоречие - это антагонизм в реализации созданной базы, которая может использоваться либо для радикальной гуманизации жизни в интересах всего живого, либо для эффективного манипулирования, что и проявляется в противостояниях интересов основных масс народа и олигархата.

Для закрепления на пристойных позициях в формирующемся мироустройстве остро необходимо:

- создание и проектное стимулирование новых платформ развития, тесно коррелирующих с выращиванием адекватных времени вариантов проявления базовых ценностно-смысловых комплексов своего культурно-цивилизационного мира и экологически чистыми циклами воспроизводства на основе передовых технико-технологических укладов,

- кардинальное укрепление организационно-управленческих форм глубокой науки и прорывных технологий в эффективных моделях научно-образовательно-производственных кластеров,

- обновление систем укрепления общественного иммунитета к мутациям и воздействиям, предупреждения распространения вредоносных вирусов (в т.ч. информационных),

- запрет на работы с разнообразным ОМП (в частности, бактериологическим),

- повышение уровня территориального рассредоточения как производств, так органов власти и управления. Практика напомнила: географическая диверсификация экономической, социальной, политической жизни - условие успешного преодоления очаговых вспышек эпидемии, в конечном итоге - и устойчивости государства и общественного порядка.

Тем самым, для человечества актуализировался вопрос оптимизации использования периода «зацикленности Запада на себя», в частности, для освобождения от внешней зависимости и упрочения суверенности, а также предотвращения угрозы возможного перерастания гражданской войны в бывшем гегемоне в мировой конфликт. Очевидно, что требуется в наибольшей степени использовать открывшийся шанс эффективной как защиты своих национальных 
интересов, так и тесно связанного с этим выращивания более справедливого и прогрессивного порядка мировой жизни. Если послевоенный мир сумел осуществить материально-политическую деколонизацию, теперь же на повестке дня - духовно-нравственная. Безусловно, каждый культурно-цивилизационный мир имеет право культивировать собственный путь органичного развития, создавая свои Сверхпроекты и особенную социоприродную целостность на основе своих базовых ценностно-смысловых комплексов. Для этого необходима как спокойная уверенность в исторической правоте, так и защищённость народа. Восстановление кадровой, образовательной, научно-инновационной, промышленной, инфраструктурной и др. подсистем общественной жизни -необходимость создания альтернативной действующим модели мировоззрения и мироосвоения (в т.ч. ресурсами экономической и финансовой деятельности). Приоритетом стратегического управления становится очеловечивание общественной жизни и создание социальных условий свободы и творчества для наиболее полного осуществления и развития глубоко индивидуального комплекса одарённости каждого. Глубоко личностный характер одарённости отражается в интегральных качествах материального и духовного производства, в ассоциировании и кооперировании деятельности по созданию и распространению предметов культуры, навыков и знаний. Общественно полезное раскрытие научно-интеллектуального потенциала предполагает наличие и развитие его ценностного основания. Стимулирование использование способностей персонала требует усиления гуманизации социально-экономических отношений как направления интеллектуализации воспроизводства. Сочетание разумной предосторожности и инициативы наполняет смыслом развитие экологической культуры хозяйствования, формирует процесс стратегического планирования. При масштабных переменах: структурных, организационно-управленческих, функциональных и проч. - востребованность стратегического планирования (в частности, на основе межотраслевых балансов) резко возрастает. Вместе с тем, особенностью социально-экономических пространств в этот период выступает сложнопрогнозируемый характер вектора и динамики развития.

Разумеется, усилия общества в переходный к новой общественной парадигме период сосредотачиваются как на создании научно-образо- 
вательно-производственных кластеров, так и на культивировании стимулирующей позитивные изменения общественной среды. Государство (в том числе и при поддержке местного самоуправления) берет на себя рутинно-повседневные (в частности, коммунально-бытовые) функции и задачи. Расширение задач государственного управления и социальной экономики - естественные направления в осовременивании социального государства. Наличие органичного комплекса общественных регуляторов - условие прогресса, усложнение этих регуляторов - признак прогресса, необходимость соответствия управляющей системы управляемой целостности. Более того, чем более соответствующим конкретике становится решение, тем более богатый арсенал возможностей оно открывает. Чем выше разнообразие оснований, чем более сложной является внутренняя структура, тем она более устойчива в периоды и относительной стабильности, и форсированных изменений, тем более способна к развитию. Однако, очевидно, работа со сложноорганизованным обществом требует как, в целом, повышенной социальной ответственности, так и, в частности, сочетания компетентности, профессионализма с нравственным ригоризмом.

\section{4. Выводы}

Обеспечение экологичности процесса социально-экономического воспроизводства и специализация на создании экологически чистого продукта - необходимость достойного участия в экономике новой эпохи. Культивирование общественной среды, способствующей развитию и реализации в творчестве сущностных сил человека, а также точек концентрации желательных перемен - решающий фактор формирования «зелёного» уклада экономики. Влияние требований экологии (в т.ч. экологии человека) настолько усиливается, что природосбережение входит в адекватное эпохе понимание общественной формы производительного труда. Общее повышение экологической грамотности будет опираться на разные народные традиции, отличаться в многообразии форм. Так, становление устойчивого состояния гармоничной социобиологической целостности требует достижения динамичного единства мер обеспечения поддержания безопасности и развития. Соответственно, экономика включается в качестве подсистемы в природную среду. Ресурсно-ориентированная экономика не 
может не признавать первоочередного значения экологических факторов безопасности и развития общества, в частности - при изучении обоснованности применения технологий. Вместе с тем, культивирование экологических приоритетов как элемент поддержания жизни и цивилизации, разумеется, отнюдь не является основанием для отказа от развития или же слоганов в апологии торможения развитыми странами развивающихся. Напротив, значимая задача «зелёной» экономики - оказать толчок в переходе к новым общественным горизонтам. Сохраняя достигнутый уровень обобществления социально-экономической жизни, ойкумена упёрлась в препятствие своим безопасности и развитию, связанное с сохранением устаревшей организации миропорядка, обслуживаемой идеями то вульгарного мультикультурализма, то примитивного национального эгоизма. Органичному движению вперёд свойственно преодоление однобокости подходов в пользу стереоскопичности, объёмности понимания явлений и процессов с голографичностью миропонимания. Доминирующий тип политико-экономического устройства и господствующая модель изменений не вполне отвечают запросам общества и возможностям новой эпохи. Уже стало очевидно, что ориентации на потребительское общество как сумму «экономических животных» не только не позволяют выжить в условиях катастрофы, но и исторически обречены. Причём кардинальное переструктурирование глобального мироустройства уже преодолело свою «точку невозврата». Стали вполне заметны не только основные варианты решений, но и главные черты нового устройства международной архитектоники, тесно связанные с характеристиками внутренних трансформаций. От следования модели, признаваемой генерализующей, мир переходит к принципиальной множественности разнокачественных подходов, включающих в себя и цели экологического возрождения, сводимых воедино за счёт общепризнанных и взаимоприемлемых стандартов. И повышение эффективности использования каждым субъектом международных экономических отношений своего потенциала, высвобождение преимуществ и компенсации недостатков / уязвимостей предполагает сознательность и скоординированность усилий. Время форсированного осуществления стратегических перемен, таким образом, означает обновление общественных и технико-технологических форм культурно-цивилизационного мира, 
но без слома, а, как раз напротив, при бережном развитии своих традиций и подходов.

В период социетальных форсированных изменений народы особенно подвержены как позитивным, так и негативным мутациям, точка бифуркации - положение наибольшей свободы, когда удар совсем не должен быть сильным, главное - точным. Крайне существенен вопрос о субъекте преобразований. От того, кто и в чьих интересах определяет конечный вектор изменений, во многом и зависит, будет ли Ойкумена двигаться к созданию Утопии или же Антиутопии. Получение стратегической инициативы в обеспечении суверенитета требует актуализации ресурсно-методологических баз эндогенного развития и акцентирования новейших технико-технологических укладов глубокой переработки при повышении веса интеллектоёмкого творчества, а для этого - кардинально нового уровня стратегического управления государством. Соответственно, определение баланса стратегии, тактики и оператики может стать фактором, определяющим последующую траекторию перемен. Кроме того, у формирующихся условий нового миропорядка, на переломе времён - тоже свои правила. И здесь, зачастую, риск - наименее рискованная стратегия. Особенно, если базируется на исторически оправданном сплаве традиций и инноваций.

\section{Список литературы:}

1. Швейцер А. Благоговение перед жизнью. Москва : Прогресс, 1992. 576 с.

2. Сагатовский В.Н. Философия антропокосмизма в кратком изложении. Санкт-Петербург : Изд-во СПбГУ, 2004. 231 с.

3. Острецов И.Н. Введение в философию ненасильственного развития. Москва : Великий Град, 2013. 320 с.

4. Чаянов А.В. Основные идеи и формы организации сельскохозяйственной кооперации. Москва : Наука, 1991. 455 с.

5. Shedyakov V. Social partnership in the system of organization of the social environment of effective competitiveness management. Conceptual aspects management of competitiveness the economic entities / ed. by M. Bezpartochnyi, I. Britchenko; Higher School of Social and Economic. Przeworsk : WSSG, 2019. Vol. 2. P. 222-239.

6. Бузгалин А.В., Колганов А.И. Пределы капитала: методология и онтология. Москва : Культурная революция, 2009. 680 с.

7.Кравченко С.А. Социология модерна и постмодерна в динамически меняющемся мире. Москва : МГИМО-У, 2007. 264 с.

8. Джохадзе И.Д. Демократия после Модерна. Москва : Праксис, 2006. 112 с. 
9. Шедяков В.Е. Постглобальные возможности и угрозы: диапазон решений. Economic Development: Global Trends and National Peculiarities / ed. by A. Pawlik, K. Shaposhnykov. Kielce : Baltija Publishing, 2020. P. 261-275. DOI: $10.30525 / 978-9934-588-61-7-18$

10. Шедяков В.Е. Обогащение закономерностей переходного периода конкретикой случайного. Labyrinths of Reality : Collection of scient. works / ed. by M.A. Zhurba. Montreal, 2020. Issue 4(9). P. 6-9.

11. Шедяков В.Е. Трансформации общественные и наук об обществе. Развитие экономических и межотраслевых наук в XXI веке : Ежемесячный научный журнал. Новосибирск : Научный институт глобальной и региональной экономики (НИГРЭ). 2015. № 6(13). С. 68-71.

12. About the Sustainable Development Strategy Ukraine-2020 (2015). Decree of the President of Ukraine; Strategy dated 01/12/2015. No 5/2015. URL: https://zakon2.rada.gov.ua/laws/show/5/2015

13. Шумахер Э.Ф. Малое прекрасно. Экономика, в которой люди имеют значение. Москва : ВШЭ, 2012. 352 с.

14. Шедяков В.Е. Реализация социокультурного капитала как условие полнокачественности действия человеческого фактора общественного воспроизводства. Бізнес-навігатор. 2019. Вип. 1(50). С. 12-16.

15. Warren E. This Fight Is Our Fight: The Battle to Save America's Middle Class. USA : Metropolitan Books / Henry Holt \& Company, 2017. 337 p.

16. Castells M. The Power of Identity. The Information Age: Economy, Society and Culture. Vol. II. Wiley-Blackwell, 2010. 584 p.

17. Buchanan P.J. The Death of the West. USA : St. Martin's Press, 2001. 320 p.

18. Diamond J. Guns, Germs, and Steel. The Fates of Human Societies. USA : W.W. Norton \& Company, 1997. 480 p.

\section{References:}

1. Shveytser, A. (1992). Blagogovenie pered zhizn'yu [Reverence for life]. Moscow: Progress, 576 p. (in Russian)

2. Sagatovskiy, V.N. (2004). Filosofiya antropokosmizma v kratkom izlozhenii [The philosophy of anthropocosmism in summary]. Sankt-Peterburg: Izd-vo SPbGU, 231 p. (in Russian)

3. Ostretsov, I.N. (2013). Vvedenie v filosofiyu nenasil'stvennogo razvitiya [Introduction to the philosophy of nonviolent development]. Moscow: Velikiy Grad, 320 p. (in Russian)

4. Chayanov, A.V. (1991). Osnovnye idei i formy organizatsii sel'skokhozyaystvennoi kooperatsii [Basic ideas and forms of organization of agricultural cooperation]. Moscow: Nauka, 455 p. (in Russian)

5. Shedyakov, V. (2019). Social partnership in the system of organization of the social environment of effective competitiveness management. Conceptual aspects management of competitiveness the economic entities / Bezpartochnyi, M., Britchenko, I. (eds.). WSSG, vol. 2, pp. 222-239. 
6. Buzgalin, A.V., Kolganov, A.I. (2009). Predely kapitala: metodologiya i ontologiya. [Capital limits: methodology and ontology]. Moscow: Kul'turnaya revolyutsiya, 680 p. (in Russian)

7. Kravchenko, S.A. (2007). Sotsiologiya moderna i postmoderna v dinamicheski menyayushchemsya mire [Sociology of modernity and postmodernity in a dynamically changing world]. Moscow: MGIMO-U, 264 p. (in Russian).

8. Dzhokhadze, I.D. (2006). Demokratiya posle Moderna [Democracy after Modernity]. Moscow: Praksis, 112 p. (in Russian)

Shedyakov, V.E. (2020). Postglobal'nye vozmozhnosti i ugrozy: diapazon resheniy [Post-global opportunities and threats: a range of solutions]. Economic Development: Global Trends and National Peculiarities / Pawlik, A., Shaposhnykov, K. (eds.). Kielce: Baltija Publishing, pp. 261-275. DOI: 10.30525/ 978-9934-588-61-7-18 (in Russian)

9. Shedyakov, V.E. (2020). Obogashchenie zakonomernostey perekhodnogo perioda konkretikoy sluchaynogo. Enrichment of the patterns of the transition period with the specifics of the random. Labyrinths of Reality: Collection of scient. works / Zhurba, M.A. (ed.). Montreal, issue 4(9), pp. 6-9. (in Russian)

10. Shedyakov, V.E. (2015). Transformatsii obshchestvennye i nauk ob obshchestve [Society's and social sciences transformations]. Razvitie ekonomicheskikh $i$ mezhotraslevykh naukv XXI veke: Ezhemesyachnyy nauchnyy zhurnal. Novosibirsk: Nauchnyy institut global'noy i regional'noy ekonomiki, no. 6(13), pp. 68-71. (in Russian)

11. About the Sustainable Development Strategy Ukraine-2020 (2015). Decree of the President of Ukraine; Strategy dated 01/12/2015. No 5/2015. URL: https://zakon2.rada.gov.ua/laws/show/5/2015.

12. Shumaher, E.F. (2012). Maloe prekrasno. Ekonomika, v kotoroy ludi imeut znachenie [Small is beautiful. An economy in which people matter]. Moscow: VShE, 352 p. (in Russian)

13. Shedyakov, V.E. (2019). Realizatsiya sotsiokul'turnogo kapitala kak uslovie polnokachestvennosti deystviya chelovecheskogo faktora obshchestvennogo vosproizvodstva [The action of sociocultural capital as a condition for the fulfil realization of the human factor of social reproduction]. Biznes-navighator, vol. 1(50), pp. 12-16. (in Russian)

14. Warren, E. (2017). This Fight Is Our Fight: The Battle to Save America's Middle Class. USA: Metropolitan Books / Henry Holt \& Company, 337 p.

15. Castells, M. (2010). The Power of Identity. The Information Age: Economy, Society and Culture. Vol. II. Wiley-Blackwell, $584 \mathrm{p}$.

16. Buchanan, P.J. (2001). The Death of the West. USA: St. Martin's Press, 320 p.

17. Diamond, J. (1997). Guns, Germs, and Steel. The Fates of Human Societies. USA: W.W. Norton \& Company, $480 \mathrm{p}$. 